\title{
Ekspresi mRNA BRLF1 Virus Epstein-Barr dari Biopsi Jaringan Tumor Formalin- Fixed Paraffin Embedeed Sebagai Petanda Biologi Molekul Diagnosis Karsinoma Nasofaring
}

\author{
Arin Herkilini ${ }^{1}$, P. Maria Hendrati ${ }^{1}$, Nur Signa Aini Gumilas ${ }^{2}$, Hidayat Sulistyo ${ }^{2}$ \\ ${ }^{1}$ Fakultas Biologi Universitas Jenderal Soedirman, Purwokerto \\ ${ }^{2}$ Fakultas Kedokteran Universitas Jenderal Soedirman, Purwokerto \\ E-mail : arin_herkilini@yahoo.com
}

\begin{abstract}
Nasopharyngeal carcinoma (NPC) is a malignant tumor that grows in the nasopharynx with a predilection in the fossa Rosenmuller. Epithelial malignancies are often found in populations of China and Southeast Asia, including Indonesia. The NPC incidence in year 2008 as many as 84,400 cases and 51,600 of these cases resulted in death. A total of 120 new cases per year NPC found in hospitals Prof. dr. Margono Soekarjo (RSMS), Purwokerto. The NPC is difficult to be diagnose caused its primary tumor lies closed to the skull base as well as various structures of vital organs. Therefore, methods that can detect early NPC required for inspection. The etiology of NPC is multifactorial consisting of genetic factors, factors of infection Epstein-Barr Virus (EBV) and environmental factors. EBV has two phases in the cycle of infection that is the phase of lytic and latent phase. BRLF1 has an important function as mediator transition from latent e NPC. The research aimed to analysis mRNA BRLF1 expression as a biomarker of NPC diagnosis by RT-PCR and to determine the positivity of RT-PCR method to detect the expression of mRNA BRLF1. The research design was cross sectional study. Samples were FFPE tumor biopsy of NPC WHO III and the total samples were 22 individu from Department of Pathology Anatomy, Prof. Dr. Margono SoekarjoHospital, Purwokerto with informed consent. The positivity of mRNA BRLF1 from FFPE tumor biopsy of NPC WHO III was in 63.6\%indicating a high expression.
\end{abstract}

Keywords: mRNA BRLF1, Epstein-Barr Virus, FFPE, Nasopharyngeal Carcinoma

\begin{abstract}
Abstrak
Karsinoma Nasofaring (KNF) adalah tumor ganas yang tumbuh di nasofaring dengan predileksi pada fosa Rosenmuller. Keganasan epitel sering ditemukan pada populasi Cina dan Asia Tenggara, termasuk Indonesia. Kejadian KNF di tahun 2008 sebanyak 84.400 kasus dan 51.600 kasus ini mengakibatkan kematian. Sebanyak 120 kasus baru per tahun KNF ditemukan di RSUD dr. Dr. Margono Soekarjo (RSMS), Purwokerto. KNF sulit untuk didiagnosis karena tumor utamanya terletak dekat dengan dasar tengkorak serta berbagai struktur organ vital. Oleh karena itu, metode yang dapat mendeteksi KNF awal diperlukan untuk pemeriksaan. Etiologi KNF bersifat multifaktorial yang terdiri dari faktor genetik, faktor infeksi Virus Epstein-Barr (EBV) dan faktor lingkungan. EBV memiliki dua fase dalam siklus infeksi yaitu fase fase litik dan laten. BRLF1 memiliki fungsi penting sebagai mediator transisi dari laten ke fase litik. Ekspresi mRNA BRLF1 yang dilakukan dengan metode RT-PCR dapat digunakan untuk mendukung diagnosis KNF, sehingga metode ini dapat meningkatkan efisiensi pemeriksaan KNF. Penelitian ini bertujuan untuk menganalisis ekspresi mRNA BRLF1 sebagai biomarka diagnosis KNF dengan teknik RT-PCR dan untuk mengetahui sensitivitas metode RT-PCR untuk mendeteksi ekspresi mRNA BRLF1. Desain penelitiannya adalah penelitian cross sectional. Sampel adalah biopsi tumor FFPE dari pasien KNF WHO III dan total sampel adalah 22 individu pada Departmen Patologi Anatomi, Rumah Sakit Prof. Dr. Margono Soekarjo, Purwokerto dengan informed consent. Hasil penelitian menunjukkan bahwa positivitas ekspresi mRNA BRLF1 dari biopsi tumor FFPE NPC WHO III adalah 63,6\% yang menunjukkan ekspresi tinggi.
\end{abstract}

Kata kunci : $m R N A B R L F 1$, Epstein-Barr Virus, FFPE, Karsinoma Nasofaring

\section{Pendahuluan}

Penyakit kanker merupakan salah satu masalah kesehatan yang penting di dunia. Angka kejadian dan kematian akibat kanker terus meningkat setiap tahunnya. Salah satu jenis penyakit kanker adalah karsinoma nasofaring. Karsinoma nasofaring (KNF) merupakan penyakit genetik multifaktor yang endemik yang mempunyai perbedaan yang signifikan dalam distribusi geografis (Jemal et al.,2011).

Insidensi KNF diperkirakan ada sekitar 84.400 kasus dan 51.600 kematian pada tahun 2008, di mana insidensi ini mewakili sekitar 0,7 persen dari semua insidensi kanker secara global. Insidensi KNF menduduki urutan ke-24 di seluruh dunia dan urutan ke-22 di negara berkembang dari semua insiden kanker (Jemal et al., 2011). $\mathrm{KNF}$ relatif rendah di dunia yaitu umumnya kurang dari 1 per 100.000 penduduk per tahun, namun insidensi KNF ditemukan tinggi pada penduduk yang hidup di Cina Selatan dan di daerah Cina lainnyayaitu 50 per 100.000 penduduk per tahun (Haryanto \&Mubarika, 2000), beda halnya dengan Amerika dan Eropa yaitu 0,5 per 100.000 penduduk per tahun dan hanya $1-2 \%$ dari seluruh tumor ganas kepala dan leher (Munir et al., 2007). KNF mempunyai perbedaan signifikan dalam distribusi geografis dan etnis. Insidensi KNF pada pria cenderung lebih tinggi dibandingkan wanita dengan rasio 2,3:1 (Chang \& Adami, 2006). 
Data dari berbagai rumah sakit di Indonesia menunjukkan bahwa KNF merupakan tumor ganas bidang THT yang paling banyak dijumpai di Indonesia dan menduduki urutan. Insidensi KNF di Indonesia hampir merata di setiap daerah; di Rumah Sakit Cipto Mangunkusomo (RSCM) Jakarta ditemukan lebih dari 100 kasus setahun, RS. Hasan Sadikin Bandung 60 kasus, Makassar 25 kasus, Palembang 25 kasus, Denpasar 15 kasus, 11 kasus di Padang dan Bukittinggi, serta 120 kasus per tahun di RSUD Prof. Margono Soekarjo (RSMS) Purwokerto. Demikian pula di Medan, Semarang, Surabaya dan kota-kota lainnya menunjukkan distribusi KNF yang merata di Indonesia (Notopuro, 2008). Di wilayah Kabupaten Banyumas, insidensi KNF menunjukan peningkatan 3,3 kali pada tahun 2009 dibandingkan dengan tahun 2008 jumlah pasien baru KNF pada tahun 2009 sebanyak 119 orang (Hafiidhaturrahmah, 2010). Berdasarkan rekam medis RSUD Prof. Dr. Margono Soekarjo jumlah kunjungan pasien KNF pada tahun 2013 sebesar 371 pasien dengan perincian 74 pasien berasal dari wilayah Kabupaten Banyumas, sedangkan pada tahun 2014 jumlah kunjungan pasien KNF sebanyak 332 pasien dengan perincian 73 pasien berasal dari wilayah Kabupaten Banyumas (Dinas Kesehatan Banyumas, 2014).

Etiologi KNF bersifat multi faktor yang terdiri dari faktor genetik, faktor lingkungan, dan faktor infeksi Epstein-Barr virus (EBV) (Fields et al., 1996). Faktor genetik penyebab KNF yaitu kelainan kromosom, polimorfisme gen. Faktor lingkungan yang dapat menimbulkan penyakit KNF yaitu sering memakan ikan asin dan makanan yang diawetkan. Hal ini didukung oleh pernyataan Liebowitz (1994) bahwa, peningkatan insidensi KNF juga dilaporkan berkaitan erat dengan faktor makanan, seperti makanan yang diawetkan, difermentasi, dan diasapi.

Infeksi Epstein-Barr Virus (EBV) merupakan faktor penyebab utama timbulnya KNF. Epstein Barr-Virus (EBV) adalah herpesvirus limfotropik yang dapat menginfeksi dan bereplikasi dalam sel epitel dan limfosit B (Alex \& Jenson, 2006). Menurut Kuo et al. (2001) keberadaan EBV pada penderita KNF dapat diketahui dengan ditemukannya DNA EBV dalam spesimen biopsi jaringan penderita KNF. Virus EBV ini dapat pula menyebabkan pertumbuhan immortal limfosit B pada penderita KNF (Savitri \& Sofia, 2005).

Genom EBV merupakan DNA untai ganda yang tertutup oleh protein kapsid berbentuk ikosahedral dikelilingi oleh amplop lipid yang mempunyai tonjolan glikoprotein. Gen yang diekspresikan pada fase laten yaitu gen EpsteinBarr Virus NuclearAntigen (EBNA), Latent Membrane Protein (LMP), dan EBV Encoded RNA (EBER) (Gullo et al., 2008). Pada fase litik daur infeksi EBV terjadi serangkaian ekspresi gen litik, replikasi genom virus dan produksi virion.
Jenis gen litik EBV, antara lain BRLF1, BALF1, BZLF1, dan BCLF1.Ekspresi gen litik BRLF1 hanya ditemukan pada jaringan tumor pasien $\mathrm{KNF}$, sedangkan gen litik lain BALF1, BZLF1, BCLF1 ekspresinya tidak spesifik pada jaringan tumor KNF baik pada penderita KNF maupun individu sehat karier EBV. Ekspresi gen litik BRLF1 dapat dide teksi pada darah tepi penjamu (Feng et al., 2000). Gen litik immediate-early EBV yaitu BZLF1 dan BRLF1 berperan penting sebagai mediator transisi fase laten menuju fase litik daur infeksi EBV. Replikasi virus oleh gen BZLF1 secara efisien membutuhkan gen transaktivator lain BRLF1 (Muray et al., 2001). Rta (BRLF1 transcriptional activator) diduga memfasilitasi pertumbuhan tumor, sehingga gen BRLF1 berkontribusi terhadap perkembangan KNF. Oleh karena itu, analisis ekspresi gen litik BRLF1 dapat digunakan untuk menegakkan diagnosis KNF dan meningkatkan efisiensi dalam penanganan KNF (Brennan, 2006).

Ekspresi mRNA BRLF1 Epstein-Barr Virus merupakan petanda sensitif dan spesifik untuk diagnosis kanker karsinoma nasofaring dan memberikan bukti yang cukup menjanjikan sebagai petanda molekuler untuk deteksi dini, staging, prognosis, dan/atau pemantauan kekambuhan kanker karsinoma nasofaring (Cacais, 2008). Pengukuran aktivitas mRNA Epstein-Barr Virus (EBV) pada lokasi tumor primer, dilakukan dengan menggunakan sampel berupa blok parafin biopsi jaringan tumor KNF. Sampel ini digunakan karena mudah didapatkan, dapat digunakan kembali, untuk pengukuran aktivitas mRNA, dan penggunaannya tidak terbatas oleh waktu.

Ekspresi transkrip (mRNA) gen EBV dulu dideteksi dengan menggunakan teknik Northern Blotting. Pada saat ini, deteksi mRNA gen EBV dengan teknik reverse transcriptase PCR (RTPCR), karena teknik ini lebih sensitif untuk mendeteksi mRNA yang mengalami proses pembuangan intron (spliced mRNA) dalam jumlah kecil dan memerlukan lebih sedikit jumlah sampel klinis (Wahyono et al., 2010). Teknik reverse transcriptase PCR (RT-PCR), terdiri dari dua tahap, pertama, sintesis cDNA dari mRNA dengan cara reverse transcription dan selanjutnya amplifikasi cDNA dengan teknik PCR. RT-PCR digunakan untuk mendapatkan panjang klon DNA secara utuh dari jumlah mRNA yang sangat sedikit dan mendeteksi transkript mRNA yang unik dari sel-sel abnormal di dalam lingkungan sel-sel yang normal (Auerkari et al., 1998).

Kesulitan diagnosa dini pada KNF sampai saat ini masih merupakan masalah besar. Hal ini disebabkan oleh karena gejala penyakit yang tidak khas dan letak tumor yang tersembunyi sehingga sulit untuk diperiksa. Di samping itu, pemeriksaan serologi dan histopatologi yang belum memadai seperti pewarnaan immuno- 
histokimia serta hampir seluruh penderita datang pada stadium lanjut (Munir et al., 2007). Menurut Lu et al. (2010), hanya sekitar 0,9-2,9\% penderita yang datang pada stadium dini, dan selebihnya datang pada stadium akhir. Keadaan inilah yang menyebabkan penatalaksanaan KNF belum memberikan hasil yang memuaskan.

\section{Metode}

Penelitian dilaksanakan di Laboratorium Patologi Anatomi RSUD Prof dr.Margono Soekarjo Purwokerto, Laboratorium Genetika dan Biologi Molekuler Fakultas Biologi Unsoed, dan Laboratorium Riset Fakultas Kedokteran Unsoed. Penelitian dilakukan selama bulan September 2015 - Januari 2016.

Rancangan penelitian yang digunakan adalah penelitian deskriptif yang berbentuk studi belah lintang (cross sectional). Sampel penelitian ini adalah biopsi jaringan tumor penderita KNF yang didiagnosis pasti sebagai KNF WHO-3 dari hasil pemeriksaan Patologi Anatomi dari Poli THT RSUD Prof. dr. Margono Soekarjo, Purwokerto. Berdasarkan atas proporsi jumlah pasien KNF dibandingkan dengan kanker lain adalah 5,46 persen (Incidency Primary Cancer in Indonesia Pathology Base, 1990), maka besar sampel minimal yang diperlukan dalam penelitian ini adalah 22 orang (Sastroasmoro dan Ismael, 2002).

Isolasi RNA berdasarkan protokol kit Purelink FFPE RNA Isolation (Invitrogen, USA). Sebanyak 3-8 irisan dari 10ul sampel biopsi jaringan tumor penderita KNF $(0,5-1 \mathrm{~cm} 2)$ diambil, kemudian ditambahkan 300 4 m larutan Melting Buffer.Lysate (a) disentrifugasi dengan kecepatan 15.700xg (13.000 rpm), selama 10-20 detik.Lysate diinkubasi pada suhu $72^{\circ} \mathrm{C}$, selama 10 menit (setiap 2-3 menit dilakukan homogenisasi dengan tapping untuk melarutkan parafin. Lysate ditambahkan 20 $\mu \mathrm{l}$ Proteinase $\mathrm{K}$, kemudian divortex selama 15 detik sehingga homogen dan diinkubasi pada suhu $60^{\circ} \mathrm{C}$, selama 60 menit, sehingga diperoleh lysate non visible pada akhir inkubasi.Lysate disentrifugasi pada kecepatan 13.000 rpm, selama 1 menit. Lapisan paraffin pada permukaan lysate ditembus dengan menggunakan pipet $(1 \mathrm{~mL})$, kemudian lysate dipindahkan ke dalam tabung $1,5 \mathrm{~mL}$ baru (RNAse clean tube).Lysate ditambahkan sebanyak $400 \mu \mathrm{l}$ binding buffer, kemudian ditambahkan $800 \mu \mathrm{l}$ $100 \%$ ethanol, dihomogenasi lysate dengan divorteks. Sebanyak $700 \mu$ lysate (h) dimasukkan ke dalam spin cartridge dengan tabung koleksi (Tahap 1). Lysate (h) disentrifugasi dengan kecepatan 2900 rpm selama 1 menit. Kemudian larutan dibuang melalui spin cartridge ditampung di dalam tabung koleksi. Spin cartridge dipasangkan kembali pada tabung koleksi. Sebanyak $700 \mu$ l lysate (h) dimasukkan ke dalam spin cartridge dengan tabung koleksi (Tahap II).
Kemudian disentrifugasi lysate (h) dengan kecepatan 2900 rpm selama 1 menit. Kemudian larutan dibuang melalui spin cartridge ditampung di dalam tabung koleksi. Spin cartridge dipasangkan kembali pada tabung koleksi. Kemudian dicuci dengan wash buffer sebanyak $500 \mu \mathrm{l}$ dan diulang sebanyak 2-3 kali perlakuan. Disentrifugasi pada kecepatan 13.000 rpm selama 1 menit. Larutan yang melalui spin cartridge ditampung di dalam tabung pencuci dibuang, spin cartridge dipasangkan pada $1,5 \mathrm{~mL}$ tabung recovery.Sebanyak $50 \mu \mathrm{l}$ RNA-se free water dipanaskan pada suhu $65^{\circ} \mathrm{C}$, kemudian dimasukkan ke dalam spin cartridge dengan tabung recovery, diinkubasi selama 1 menit, disentrifugasi dengan kecepatan $13.000 \mathrm{rpm}$ selama 1 menit, larutan ditampung melalui spin cartridge delam tabung recovery sehingga akan diperoleh larutan RNA kualitas I dengan volume $50 \mu \mathrm{l}$. Prosedur elusi sekali lagi diulang, diperoleh larutan RNA kualitas II.Larutan RNA bisa digunakan untuk analisis RT-PCR dengan diletakkan di atas es. Larutan RNA bisa disimpan pada suhu $-80^{\circ} \mathrm{C}$ (dalam jangka waktu lama).

Sintesis cDNA berdasarkan protokol kit Super Script III First Strand System (Invitrogen, USA). Annealed RNA mix dibuat dalam volume 10 $\mu \mathrm{L}$ dengan komposisi sebagai berikut : $50 \mu \mathrm{M}$ Oligo $d(T) 20$ primer sebanyak 1,0 $\mu \mathrm{L}$ (1x reaksi), $10 \mathrm{mM}$ dNTP mix sebanyak 1,0 $\mu \mathrm{L}$ (1x reaksi), template RNA sebanyak 7,0 $\mu \mathrm{L}$ (1x reaksi), DEPC- treated water sebanyak 1,0 $\mathrm{LL}$ (1x reaksi). Diinkubasi di waterbath pada suhu $65^{\circ} \mathrm{C}$ selama 5 menit dan diletakkan di atas es selama 2-3 menit.Dibuat cDNA synthesis mix pada volume 10 $\mu \mathrm{L}$ dengan komposisi sebagai berikut : $10 \times \mathrm{RT}$ Buffer sebanyak 2,0 $\mu \mathrm{L}$ (1x reaksi), $25 \mathrm{Mm} \mathrm{MgCl} 2$ sebanyak 4,0 $\mu \mathrm{L}$ (1x reaksi), 0,1 DTT sebanyak 2,0 $\mu \mathrm{L}$ (1x reaksi), RNaseOUT (140 U/ $\mu \mathrm{L})$ sebanyak 1,0 $\mu \mathrm{L}$ (1x reaksi), Superscript III RT $(200 \mathrm{U} / \mu \mathrm{L})$ sebanyak 1,0 $\mu \mathrm{L}$ (1x reaksi). Dicampurkan Annealed RNA Mix dan cDNA synthesis mix diinkubasi di waterbath pada suhu $50^{\circ} \mathrm{C}$, selama 50 menit dan diinkubasi pada waterbath pada suhu $85^{\circ} \mathrm{C}$, selama 5 menit. Sebanyak $1 \mu \mathrm{L}$ Rnase $\mathrm{H}$ dicampurkan, selanjutnya diinkubasi di waterbath pada suhu $37^{\circ} \mathrm{C}$, selama 20 menit.

Teknik RT- PCR digunakan untuk mendeteksi ekspresi mRNA BRLF1 pada sampel penderita KNF WHO-3. Primer yang digunakan pada RT- PCR akan menghasilkan amplikon fragmen cDNA berukuran 157 pb. Campuran PCR dibuat berdasarkan protokol kit Dream Taq PCR kit (Thermo Scientific, USA) dibuat dalam volume $15 \mu \mathrm{L}$ yang komposisinya terdiri dari 7,5 $\mu \mathrm{L}$ Dream Taq PCR Master Mix (Dream Taq DNA Polymerase, 2X Dream Taq Buffer, $4 \mathrm{mM} \mathrm{MgCl}_{2}$, 0,4 mM dGTP, 0,4 mM dATP, 0,4 mM dCTP, 0,4 $\mathrm{mM}$ dTTP), 1,0 $\mu \mathrm{M}$ primer sisi kiri (forward/left primer) adalah 5' 
AGCAGAGCGAGCGGGAAGAG-3' dan primer sisi kanan (reverse/right primer) adalah 5'TCGCTCTCTTGGTGGACCGC-3', $\mathrm{ddH}_{2} \mathrm{O}$ (water PCR grade) $5 \mu \mathrm{L}$ dan $0,5 \mu \mathrm{g} / \mu \mathrm{L}$ cetakan DNA.Campuran PCR ini dimasukkan dalam mesin PCR (Applied Biosystem Thermocycler -Verity 96 well, USA). Tahap amplifikasi dilakukan pada mesin PCR sebanyak 35 siklus dengan kondisi PCR sebagai berikut : denaturasi awal $95^{\circ} \mathrm{C}$ selama 3 menit, denaturasi $95^{\circ} \mathrm{C}$ selama 30 detik, penempelan $62,4^{\circ} \mathrm{C}$ selama 2 menit 30 detik, pemanjangan $72^{\circ} \mathrm{C}$ selama 1 menit 30 detik, pemanjangan akhir $72^{\circ} \mathrm{C}$ selama 5 menit. Hasil RT-PCR dipisahkan dengan elektroforesis gel agarose $1 \%$. Hasil elektroforesis tersebut kemudian divisualisasi dengan Gel-Doc 1000. (Hitachi, Japan).

\section{Hasil dan Pembahasan}

Konsentrasi cDNA diukur menggunakan nanodrop spektrofotometer. Hasil pengukuran konsentrasi cDNA berkisar 74,5-1.213 ng/ $\mu$. Kemurnian cDNA diukur nilai absorbansinya pada panjang gelombang $(\lambda)$ 260/280 $\mathrm{nm}$ dan $(\lambda)$ $260 / 230 \mathrm{~nm}$. Hasil pengukuran kemurnian cDNA $(\lambda 260 / 280)$ pada penelitian ini, berkisar antara
0,617577197-1,59193707, sedangkan pada nilai absorbansi $\lambda 260 / 230$ berkisar antara 0,505836576- 1,745922747.

Sampel diambil dari biopsi jaringan tumor KNF dalam blok parafin penderita KNF tipe WHO3 menggunakan 22 sampel yang diambil di RSUD Prof. Dr. Margono Soekarjo, diisolasi untuk dideteksi ekspresi mRNA BRLF1 menggunakan metode RT- PCR. Hasil primer-blast menunjukkan bahwa primer yang digunakan dalam penelitian ini merupakan pr imer spesifik untuk mengamplifikasi fragmen gen BRLF1 Forward primer (5'-AGCAGAGCGAGCGGGAAGAG-3') dan reverse primer (5'TCGCTCTCTTGGTGGACCGC-3') digunakan untuk amplifikasi yang akan menghasilkan fragmen DNA dengan panjang 157 bp. Hasil optimasi RT-PCR diperoleh suhu annealing yaitu $62,4^{\circ} \mathrm{C}$. Pita cDNA yang terbentuk dibandingkan ukurannya dengan DNA ladder 100 bp. Gambar 1 dan 2. menunjukkan ekspresi mRNA BRLF1 menggunakan metode RT- PCR yang menggunakan primer spesifik dan bernilai positif dengan produk berukuran 157 bp.

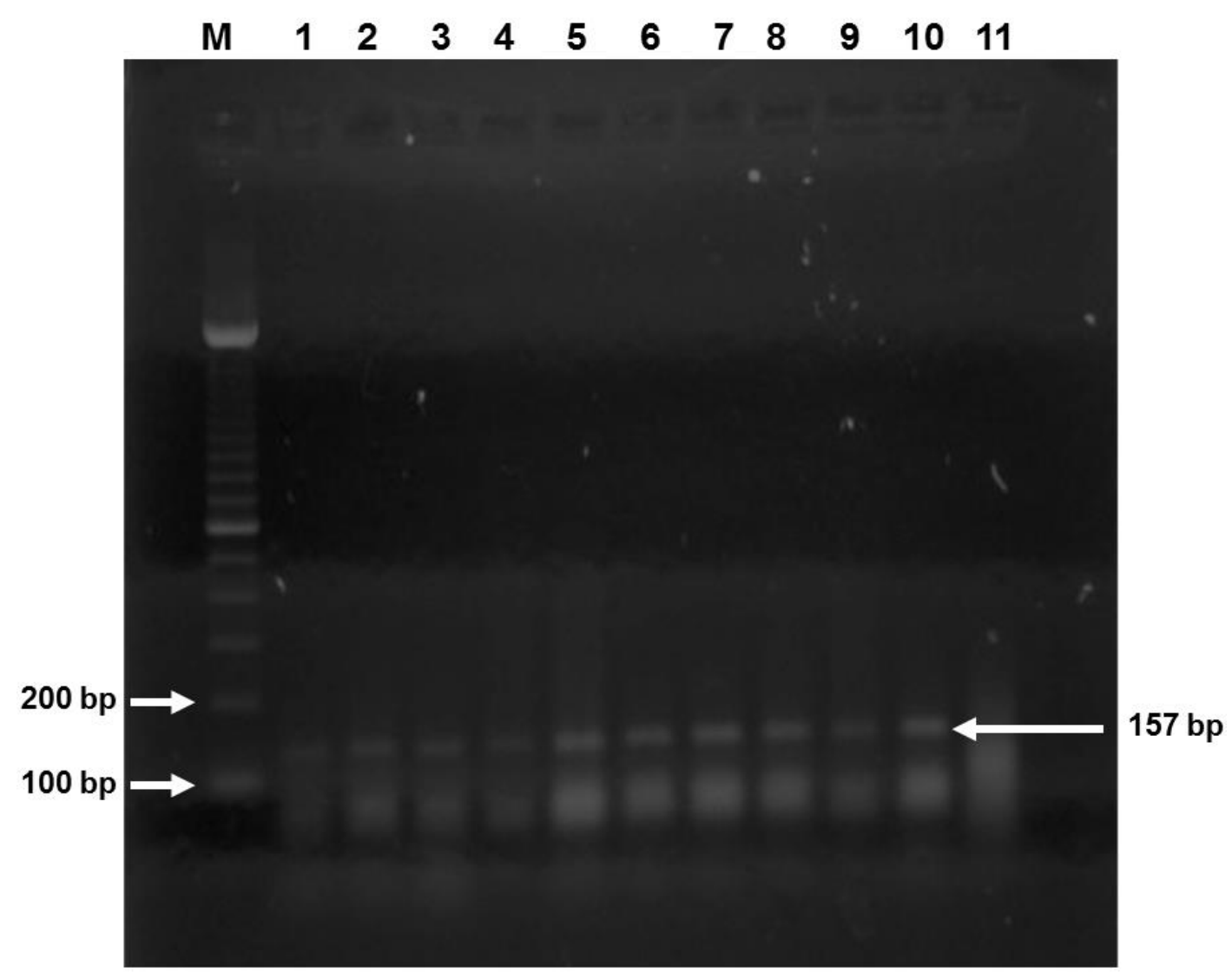

Gambar 1. Visualisasi ekpresi mRNA BRLF1 EBV dengan RT-PCR (M, Marka DNA 100 bp; Ekpresi mRNA BRLF1 EBV positif pada sumuran no. 1 - 10 (EBV-6, EBV-9, EBV-3, EBV-4, EBV-15, EBV18, EBV-17, EBV-10, EBV-2 danEBV-16).Ekpresi mRNA BRLF1 EBV negatif pada sumuran no. 11(EBV-1). 
Menurut Feng et al. (2000), jaringan tumor karsinoma nasofaring dapat mewakili replikasi litik EBV pada sel epitel. Studi yang dilakukan menggunakan beberapa gen antara lain, BZLF1, BALF2, BRLF1 dan BCLF1, baik di KNF maupun biopsi kontrol. Dalam hasil penelitian Feng et al. (2000) yang menggunakan sampel darah perifer, menunjukkan hasil ekspresi EBV IE gen BZLF1 terdeteksi 4 dari 10 pasein KNF $(40 \%)$, gen BALF2 terdeteksi 3 dari 10 pasien KNF, namun pada gen BRLF1 dan BCLF1 tidak terdeteksi dalam sampel baik KNF maupun individu kontrol. Pada sampel biopsi menunjukkan ekspresi BZLF1, BALF1, dan BCLF1 terdeteksi 5 dari 7 biopsi $\mathrm{KNF}(71,42 \%)$, serta terdeteksi 3 dari 5 biopsi kontrol (60\%), sedangkan ekspresi gen IE BRLF1 terdeteksi pada 4 dari 7 biopsi jaringan tumor KNF $(57,14 \%)$, tapi tidak terdeteksi pada 5 biopsi kontrol. Ekspresi gen BRLF1hanya dapat terdeteksi biopsi KNF saja, ini menunjukkan bahwa replikasi EBV secara in vivo pada sel tumor epitel KNF berbeda dari sel non-ganas EBV pada individu kontrol.

Berdasarkan hasil kemurnian tersebut, menunjukkan bahwa sampel penelitian terkontaminasi, baik oleh protein atau bahan organik lain. Sambrook \& Russel (2001) menyatakan bahwa DNA dengan rasio $\lambda 260$ $\mathrm{nm} / 280 \mathrm{~nm}$ pada kisaran antara 1,8-2,0 memiliki kemurnian sesuai persyaratan kemurnian dalam analisis molekuler. Pada kemurnian DNA yang nilainya lebih rendah dari 1,8 menunjukkan sampel DNA terkontaminasi oleh protein, sedangkan kemurnian DNA yang nilainya lebih tinggi dari 2,0 artinya sampel DNA terkontaminasi oleh RNA. Menurut Tenriulo et al. (2001), kontaminasi protein dan bahan organik lainnya pada larutan DNA ditunjukkan dengan nilai rasio $\lambda 260 \mathrm{~nm} / 280 \mathrm{~nm}$ adalah <1,8, sebaliknya kontaminasi fenol ditunjukkan nilai rasio tersebut $\lambda 260 \mathrm{~nm} / 280 \mathrm{~nm}$ adalah>2,0. Pada perbandingan absorbansi $\lambda$ 260/230 nm DNA murni berkisar antara 2-2,2. Jika nilainya lebih rendah dari 2 maka DNA terkontaminasi oleh karbohidrat, bahan organik, atau kemikalia lain (Boyer, 2005).

Rendahnya kemurnian cDNA ini dapat berasal dari rendahnya kemurnian RNA. Complementary DNA (cDNA) adalah DNA dibuat berdasarkan sekuen mRNA. Pembuatan cDNA melalui pemanfaatan enzim reverse transcriptase, yang melakukan sintesis DNA dari template RNA. Kuantitas RNA yang baik dibutuhkan untuk

\section{Daftar Referensi}

Adham, M., Kurniawan A. N., Muhtadi A. I., Roezin A., Hermani B., Gondhowiardjo S., Tan I. B. \& Middeldorp J. M. 2012. Nasopharyngeal Carcinoma in Indonesia: Epidemiology Incidence Signs and Symptoms at Presentation. Chinese Journal Cancer, 31(5), pp.185-196 melakukan reverse transcription yang optimal, sehingga diperoleh cDNA dengan kuantitas yang baik (Godfrey et al, 2000). Kemurnian RNA dalam penelitian ini pada $\lambda$ 260/280 adalah 0,62 - 1,59. Kemurnian RNA dan cDNA yang rendah yang rendah didapatkan dari biopsi jaringan tumor blok parafin. Formalin fixed parafin-embedded (FFPE) secara rutin digunakan untuk diagnosis histopatologi seperti kanker di rumah sakit, serta dapat digunakan sebagai bahan sampel penelitian untuk ekspresi mRNA.

Penelitian ekspresi mRNA BRLF1 EBV pada jaringan tumor KNF dalam blok parafin penderita KNF tipe WHO-3 menggunakan 22 sampel yang diambil di RSUD Prof. Dr. Margono Soekarjo, serta penelitian ini dilaksanakan pada bulan September 2015 - Januari 2016. Ekspresi mRNA BRLF1 EBV menggunakan sampel yang diambil secara consecutive sampling yaitu semua subjek yang datang dan memenuhi kriteria inklusi dimasukkan dalam penelitian sampai jumlah subjek yang diperlukan terpenuhi.

\section{Simpulan}

Berdasarkan penelitian yang telah dilakukan, dapat disimpulkan bahwa (1) Metode RT-PCR dapat digunakan untuk menganalisis ekspresi mRNA BRLF1 pada sampel biopsi jaringan dalam blok paraffin penderita KNF; (2) Positivitas ekspresi mRNA BRLF1 daribiopsi jaringan tumor FFPE adalah 63,6\%. mRNA BRLF1 daribiopsi jaringan tumor FFPE terekspresi tinggi pada penderita KNF WHO III, sehingga ekspresi mRNA BRLF1 berpotensi sebagai petanda biologi molekul potensial dalam diagnosis KNF. Perlu dilakukan penelitian Ianjutan mengenai ekspresi relatif mRNA BRLF1 EBV dengan menggunakan teknik real-time RT-PCR (RT-qPCR) dihubungkan dengan berbagai tingkat stadium KNF untuk menganalisis progresivitas tumor.

\section{Ucapan Terima Kasih}

Ucapan terima kasih disampaikan kepada Direktorat Penelitian \& Pengadian Masyarakat Kemenristekdikti atas pendanaan penelitian ini melalui Hibah Penelitian Fundamental Tahun 2015-2016 dan LPPM Unsoed sebagai pengelola pendaanan penelitian ini.

Alex, T. \& Hall B. J. 2006. Epstein-Barr Virus. New York : Taylor \& Francis Group.

Ariwibowo, Hendrawan. 2013. Faktor Risiko Karsinoma Nasofaring. Jurnal CDK/204. Vol. 40(5).

Auerkari, Sunarto, \& Ahmad D. 1998. RT-PCR (Reverse Transcription- Polymerase Chain 
Reaction): Suatu Cara Pendeteksi Perubahan-Perubahan Ekspresi Gen pada Penyakit. Jurnal Kedokteran Gigi Universitas Indonesia, 5 (3), pp. 162-165.

Barnes, Eveson J.W., Reichart P., Sidransky D (Eds.): World Health Organization Classification of Tumours. 2005. Pathology and Genetics of Head and Neck Tumours. Lyon : IARC Press, pp. 85-97.

Bhende, P. M., Seaman W. T., Delecluse H. J. \& Kenney, S. C., 2004. The EBV Switch Protein Z, Preferentially Binds and Activates the Methylated Viral Genom. Nat Genet, 36(10), pp.1999-2004.

Feng, F., Ren, E. C., Liu, D., Chan, S., Hhu, H. 2000. Expression of Epstein-Barr Virus lytic gene BRLF1 in nasopharyngeal carcinoma : potensial use in diagnosis. Journal of Genetics Virology, 81, pp. 2417-2423.

Ferreira, C., Thiemy, V., Maria., Nicole, D., Seth, A. 2004. Reverse Trancriptase PCR : Principles and Application in Dentistry. Journal of Applel Oral Science, 12 (1), pp. 1-11.

Fields, B. N., Knipe, D. M. \& Howley, P. 1996. Fields Virology. Philadelphia: LippincottRaven.

Haryanto, A., \& Sofia M., 2012. Isolasi dan Amplifikasi Gen Penyandi Domain CTerminus Latent Membrane Protein (LMPI) Epstein-barr Virus (EBV) dari Penderita Karsinoma Nasofaring (KNF). Journal of Sains Veterinary,18(2), pp.1-7.

Hafiidhaturrahmah, D.A.B., 2010. Distribusi Data Kanker Nasofaring Di RSUDMargono Soekarjo Purwokerto Tahun 2009. Referat. Purwokerto : SMF Telinga Hidung dan Tenggorokkan (THT) Fakultas Kedokteran Universitas Jenderal Soedirman.

Haryanto, A. \& S. Mubarika. 2007. Isolasi dan Amplikasi Gen Penyandi Domain CTerminal Latent Membrane Protein (Imp-1)
Epstein-Barr Viris (EBV) dari Penderita Karsinoma Nasofaring (KNF). Journal of Sains Veterinary, 17 (2), pp.1-7.

Henny, F. 2006. Ekspresi Protein Mutan p53 pada Karsinoma Nasofaring. Skripsi. Medan.:Fakultas Kedokteran Universitas SumateraUtara.

Hewajuli, Dyah Ayu., dan Dharmayanti. 2014. Perkembangan Teknologi Reverse Transcriptase-Polymerase Chain Reaction dalam Mengidentifikasi Genom Avian Influenza dan Newcastle Disease. Bogor: Balai Besar Penelitian Veteriner.

Jemal A, Bray F, Center CC, Ferlay J, Ward E, Forman D. 2011. Global cancer statistics. Cancer Journal of Clinician, 6s1, pp. 69-90.

Munir, D. 2010. Karsinoma Nasofaring. Medan: USU Press.

Rezeki, M., Parwati, I., Bethy., Tjandrawati, A. 2014. Validitas Multiplex Real Time Polymerase Chain Reaction untuk Diagnosis Limfadenitis Tuberkulosis pada Spesimen Blok Parafin. Majalah Kedokteran Bandung, 46 (3), pp. 162-167.

Roezin A \& Adham M. 2007. Karsinoma Nasofaring. Dalam : Soepardi EA, Iskandar N, Bashiruddin J, Restuti RD, editor. Buku Ajar IImu Kesehatan : Telinga Hidung Tenggorok Kepala dan Leher Edisi ke 6. Jakarta : Balai Penerbit FKUI.

Sambrook J., \& Russel, D.W., 2001. Molecular Cloning: A LaboratoryManual(Third Edition). New York : Cold Spring Harbor LaboratoryPress.

Savitri, E \& Sofia M. H. 2012.Profil Viral Load Ebstein-Barr Virus dan Titer Antibodi Ig A (VCA-P18+ EBNA-1) pada Karsinoma Nasofaring di Makassar dan Yogyakarta. Journal of Indonesian Medical Association, 62(5), pp. 174-177. 